\title{
Effect of Aloe vera extract in post-burn skin repair in rats
}

\section{[version 1; peer review: 1 approved with reservations, 1 not}

\section{approved]}

\author{
Lusiana Aulia1, Yunita Sari Pane (iD)2 \\ ${ }^{1}$ Faculty of Medicine, Universitas Sumatera Utara, Medan, North Sumatera, 20155, Indonesia \\ ${ }^{2}$ Pharmacology and Therapeutics, Universitas Sumatera Utara, Medan, North Sumatera, 20155, Indonesia
}

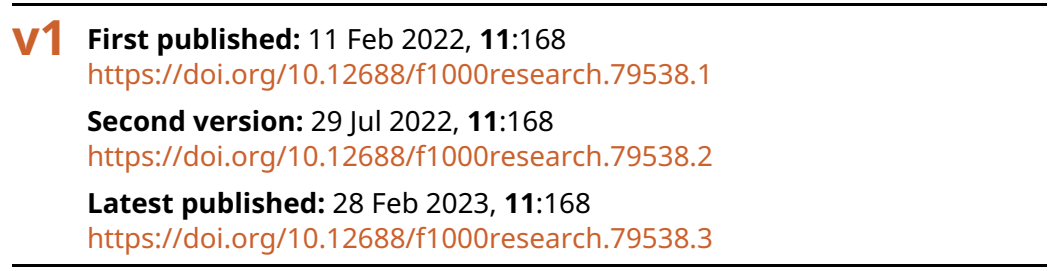

\section{Abstract}

Background: Burn injury is a global health problem that is most often caused by heat. Burn injury can cause high morbidity and mortality and requires high cost. Therefore, the use of plants as herbal medicine has the potential to be developed in Indonesia. Aloe vera contains various active ingredients that help the wound healing process, such as glucomannan and acemannan which have the effects on the proliferation of macrophages, and fibroblasts, and reepithelialization. This study aimed to determine the effect of Aloe vera extract in repairing post-burn skin in rats that was analyzed from the number of macrophages and fibroblasts, and epidermal thickness. Methods: This is an experimental study with a posttest-only control group design using 54 Rattus norvegicus Wistar strain rats. The sampling method was simple random sampling consisting of 3 groups, i.e., I. standard group, which were normal rats; II. negative control group, which were given second-degree burns and treated with gel base (without Aloe vera extract); III. treatment groups, which were given second-degree burns and treated with Aloe vera extract gel. Each group was subdivided into three smaller groups $(n=6)$ according to the time the lesions were evaluated. Skin tissue samplings were carried out on day 3, 14, and 21 after injury to observe the number of macrophages and fibroblasts, and epidermal thickness.

Results: There were significant differences in the mean number of macrophages, number of fibroblasts, and epidermal thickness in all groups $(p<0.05)$.

Conclusion: Aloe vera extract gel could accelerate the healing process of burns in rats.

\section{Keywords}

burn injury, Aloe vera, macrophages, fibroblasts, epidermal thickness

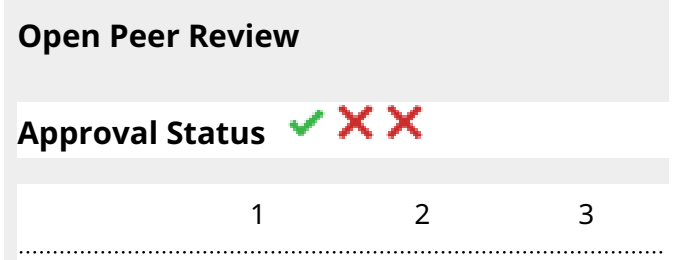

version 3

(revision)

28 Feb 2023

version 2

(revision)

29 Jul 2022

version 1

11 Feb 2022

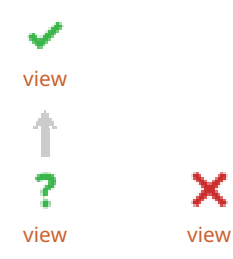

1. Gusbakti Rusip (D), Universitas Prima

Indonesia, Sumatera Utara, Indonesia

2. Fatima Ali (D), University of Lahore, Lahore, Pakistan

3. Reza Vaghardoost ID, University of Lahore,

Lahore, Pakistan

Any reports and responses or comments on the article can be found at the end of the article. 
This article is included in the Plant Science

gateway.

Corresponding author: Yunita Sari Pane (yunita@usu.ac.id)

Author roles: Aulia L: Conceptualization, Formal Analysis, Investigation, Writing - Original Draft Preparation; Pane YS:

Conceptualization, Formal Analysis, Writing - Original Draft Preparation, Writing - Review \& Editing

Competing interests: No competing interests were disclosed.

Grant information: The author(s) declared that no grants were involved in supporting this work.

Copyright: ๑ 2022 Aulia L and Pane YS. This is an open access article distributed under the terms of the Creative Commons Attribution License, which permits unrestricted use, distribution, and reproduction in any medium, provided the original work is properly cited.

How to cite this article: Aulia $L$ and Pane YS. Effect of Aloe vera extract in post-burn skin repair in rats [version 1; peer review: 1 approved with reservations, 1 not approved] F1000Research 2022, 11:168 https://doi.org/10.12688/f1000research.79538.1

First published: 11 Feb 2022, 11:168 https://doi.org/10.12688/f1000research.79538.1 


\section{Introduction}

Burn injury is a damage to the skin or other tissues that can be caused by heat, radiation, electricity, chemicals, or friction, but most often caused by heat (American Burn Association, 2019). Burn injury that is due to heat consists of three causes, which are burns due to hot liquids (scalds), flames (flame burns), or hot solids (contact burns) (World Health Organization, 2018). Burn injury can be divided into four degrees based on its depth. A first-degree burn is limited to the epidermis. Second-degree burns involve both epidermis and dermis. Third-degree burns involve epidermis, dermis, and dermal appendages. Lastly, fourth-degree burns can penetrate into subdermal fat, underlying fascia, muscle, and/or bone (ABA, 2018).

Burn injury can cause high morbidity and mortality and its treatment requires high cost. This is because of the long-term outpatient care, such as dressing changes and some even require surgical reconstruction (Smolle et al., 2017). WHO stated that around 180,000 deaths every year are caused by burns and majority occur in lower-middle-income countries due to lack of adequate facilities to reduce the incidence of burns (Menkes, 2019; WHO, 2018). According to the data from "Riset Kesehatan Dasar" RISKESDAS (Basic Health Research, Indonesia) in 2018, the proportion of burn injury in Sumatera Utara was $1 \%$ and based on the medical record data from Haji Adam Malik Hospital in Medan, North SumatraIndonesia, there were 353 cases of burns in 2011-2014 (Maulana, 2014).

There are three phases of wound healing, namely the inflammatory, proliferative and remodeling phases. The inflammatory phase is characterized by the migration of leucocytes such as macrophages to burn site to degrade debris or microbes. Next is the proliferative phase where the process of angiogenesis, re-epithelialization, and fibroblast proliferation occurs. Lastly, the remodeling phase is characterized by collagen remodeling, wound contraction, and decreased blood flow (Reinke \& Sorg, 2012).

Several studies have shown that the use of silver sulfadiazine drug can cause side effects such as leukopenia and renal toxicity (Chaby et al., 2005; Fuller \& Engler, 1988). Therefore, alternative treatments such as the use of herbal medicine is relatively safer. A number of medical plants grow in Indonesia due to favorable tropical natural conditions. The information about these herbs is passed down from one generation to another, and they are commonly used in traditional medicine, forming an integral part of Indonesian cultural heritage (Gazali et al., 2013). One of the herbs that can be used for the treatment of burns is Aloe vera. The active chemical constituents found in Aloe vera such as glucomannan and acemannan can stimulate the activity and proliferation of fibroblasts. Acemannan can also increase the number of macrophages and stimulates fibroblast to produce keratinocyte growth factor-1 (KGF-1) for re-epithelialization process (Jettanacheawchankit et al., 2009; Sierra-García et al., 2004; Surjushe et al., 2008). This study aimed to determine the effect of Aloe vera extract in repairing post-burn skin in rats that was analyzed from the number of macrophages, and fibroblasts, and epidermal thickness.

\section{Methods}

This is an experimental study in an animal burn-model with a posttest-only control group design. This study is reported in lines with the in-vivo Animal Research: Reporting guidelines ARRIVE.

Ethics

This study was approved by the Research Ethics Committee of Universitas Sumatera Utara (No. 711/KEP/USU/2021). This study was conducted at the Pharmacology Laboratory of the Faculty of Medicine, Universitas Sumatera Utara.

\section{Experimental Animal}

Healthy male Wistar strain rats, 10-12 weeks old, weighing 150-200 g were purchased from the Department Biology of Mathematics and Scientific Faculty, Universitas Sumatera Utara. Before starting the experiment, the animals were adapted for 7 days. They were kept in plastic cages $(30 \times 20 \times 20 \mathrm{~cm})$ and covered with fine wire mesh; base of cages was covered with rice husks as thick as $0.5-1 \mathrm{~cm}$ and replaced every day during the study. They were kept in 12 hours of daylight (06:00 A.M. - 06.00 P.M.) and 12 hours of dark cycle (06:00 P.M. - 06.00 A.M.) and fed with standard feed (CP 551 from PT Charoen Pokphand-Indonesia) and water was given ad libitum. They were kept in cages that were maintained at room temperature and humidity at normal ranges.

\section{Allocation and treatment groups}

All animals were randomly divided into three big groups by simple random sampling. Group I (standard) consisted of normal rats, group II (negative control) was inflicted a burn wound and treated with gel base, and group III (treatment group) was inflicted with a burn wound and treated with Aloe vera gel. Each group was subdivided into three smaller groups ( $n=6$ per group) according to the time the when the lesions were evaluated. They were treated twice a day according to the groups. 
The sample size was calculated according to Federer's formula: (Federer, 1963)

$$
(\mathrm{t}-1)(\mathrm{n}-1) \geq 15
$$

$\mathrm{t}=$ the number of groups

$\mathrm{n}=$ the number of samples

$\mathrm{n}=2.875 \approx 3 \mathrm{rat} / \mathrm{group}$

Considering the NC3Rs principal in experimental animal, statistical analysis necessity, and the possibility of drop out, the number of rats per group were determined to be six. All 54 rats were given a number (1-54) using a marker pen, then randomized by putting the numbers in an envelope and dividing them into 9 groups, according to the numbers taken from the envelope (Russell and Burch, 1992).

\section{Wound infliction}

To ensure that the rats remain in a comfortable condition, they were given anesthesia before performing the burn. The animals were anesthetized with Ketamine/Xylazine $0.2 \mathrm{~mL}$ by intraperitoneal injection (in accordance with the provisions of Vertebrate Animal Research). The hair at dorsal region was shaved and cleansed with alcohol swab. Seconddegree burn wound was inflicted using iron plate measuring $2 \times 2 \mathrm{~cm}^{2}$ which was warmed in boiling water for 5 minutes and placed for 30 seconds on the shaved area (Kristyaningsih, 2016).

\section{Aloe vera extract}

About $2000 \mathrm{~g}$ of Aloe vera leaves were collected. The bottom part and the serrated edges of Aloe vera leaves were cut and peeled to obtain the inner clear gel. About $1000 \mathrm{~g}$ of inner gel was weighed and washed thoroughly and cut it into small pieces. Then, the small pieces of gel and $2000 \mathrm{~mL} \mathrm{70 \%} \mathrm{ethanol} \mathrm{was} \mathrm{blended} \mathrm{and} \mathrm{poured} \mathrm{into} \mathrm{a} \mathrm{closed} \mathrm{container} \mathrm{(stirred}$ occasionally for 6 hours, then set aside for 18 hours). This mixture was then filtered to obtain the filtrate (I). The extraction process was repeated on the residue using $1000 \mathrm{~mL} \mathrm{70 \%} \mathrm{ethanol} \mathrm{to} \mathrm{obtain} \mathrm{another} \mathrm{filtrate} \mathrm{(II).} \mathrm{The} \mathrm{filtrate} \mathrm{(I)} \mathrm{and} \mathrm{(II)} \mathrm{were}$ mixed and evaporated using a vacuum rotary evaporator (Heidolph Instruments $\mathrm{GmbH} \& \mathrm{Co}$. KG, Germany) at $40^{\circ} \mathrm{C}$ to obtain a thick extract.

\section{Gel preparation}

\section{- Gel base}

About $400 \mathrm{cc}$ of distilled water was taken into the mortar, then $12 \mathrm{~g}$ of $3 \%$ Sodium-Carboxymethyl cellulose (Na-CMC) powder was evenly added. It was closed and set it aside for 15 minutes. After which it was ground and $4 \mathrm{~g}$ of $1 \%$ glycerin was added until a homogeneous gel base was formed.

- Aloe vera gel

Put $40 \mathrm{~g}$ of Aloe vera extract into the mortar then add $360 \mathrm{~g}$ of gel base gradually while grinding it until homogeneous.

\section{Hematoxylin and eosin (H\&E) staining}

Six animals of each groups were sacrificed on the $3^{\text {rd }}, 14^{\text {th }}$, and $21^{\text {st }}$ days after injury by injecting $100 \mathrm{mg} / \mathrm{kg}$ ketamine intraperitoneally. Then, the injured tissues were carefully dissected and fixed with $10 \%$ formalin. All samples were taken to Anatomic Pathology Laboratory of the Faculty of Medicine, Universitas Sumatera Utara for H\&E staining. The number of macrophages and fibroblasts, and epidermal thickness was evaluated using Olympus CX21 light microscope with $400 \times$ magnification and three fields of view.

\section{Statistical analysis}

Data were analyzed using SPSS version 20 (RRID:SCR_019096) with one-way ANOVA test. If there were significant differences $(p<0.05)$, then LSD test was conducted to determine the differences among groups. Data were presented as mean $\pm \mathrm{SD}$.

\section{Results}

The results obtained from the study are shown in Fig. 1-3. From the one-way ANOVA results, there were significant differences in the mean number of macrophages and fibroblasts, and epidermal thickness in all groups $(p<0.05)$. Then, least Significant Difference (LSD) test was conducted to determine the differences among groups. 


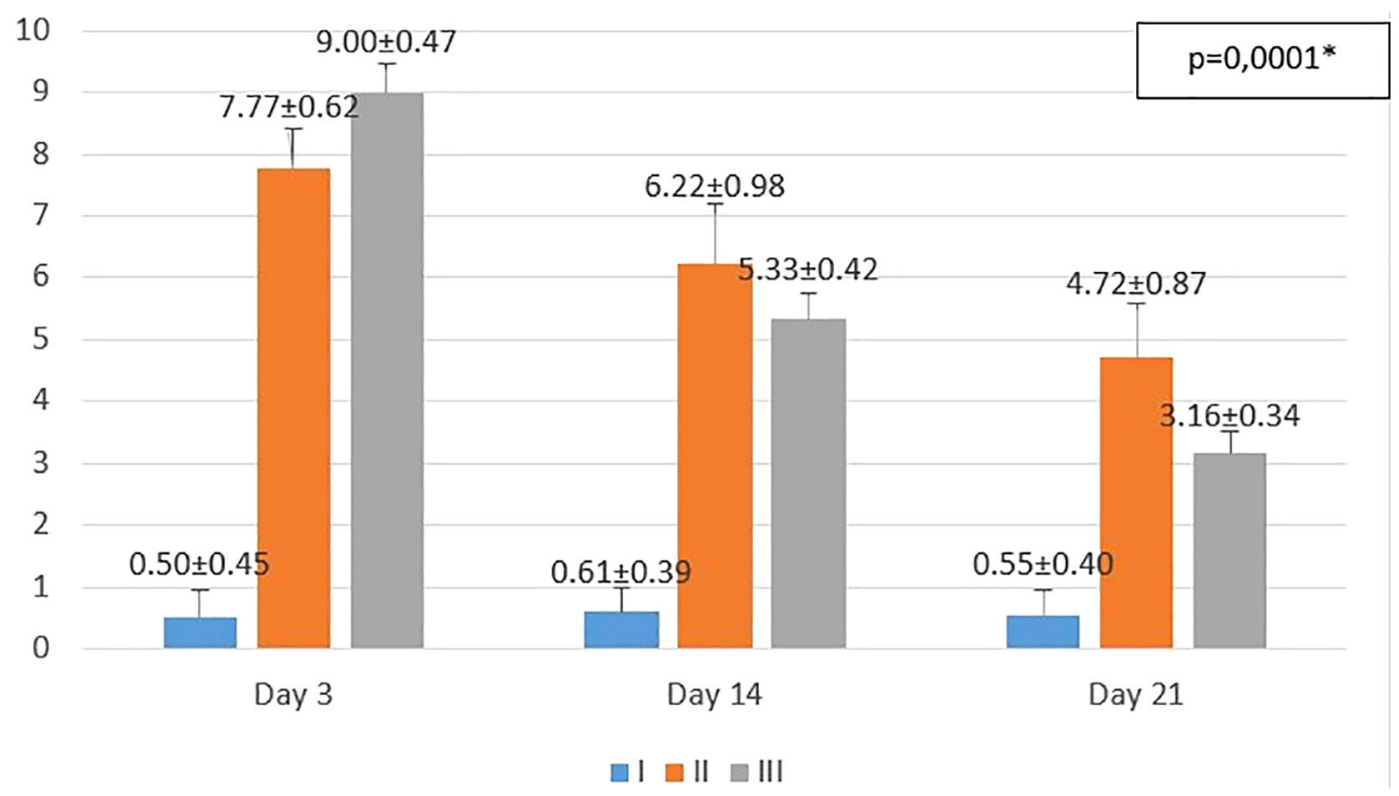

Figure 1. Mean number of macrophages I (standard), II (negative control), III (treatment) * $p<0.05$ statistically analysis by ANOVA showed significant difference.

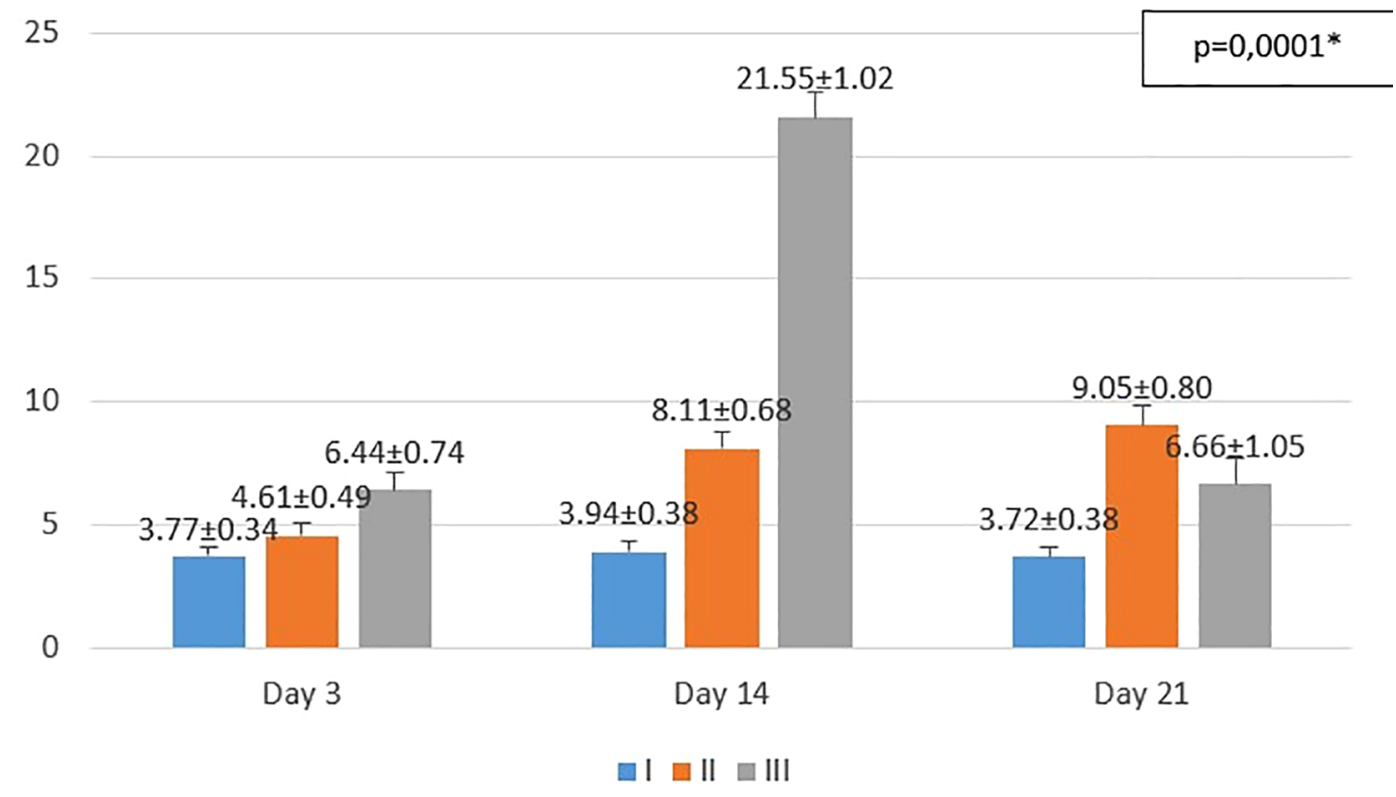

Figure 2. Mean number of fibroblasts I (standard), II (negative control), III (treatment) * $p<0.05$ statistically analysis by ANOVA showed significant difference.

On the $3^{\text {rd }}$ day after injury, the highest mean number of macrophages were seen in the treatment group (III), followed by the negative control group (II), and followed by the standard group (I). From the post hoc test results, it appeared that there were significant differences in the mean number of macrophages $(\mathrm{p}<0.05)$ in groups I-3 vs II-3 $(0.50 \pm 0.45$ vs $7.77 \pm$ $0.62 ; \mathrm{p}=0.0001)$, group I-3 vs III-3 ( $0.50 \pm 0.45$ vs $9.00 \pm 0.47 ; \mathrm{p}=0.0001)$, and group II-3 vs III-3 (7.77 \pm 0.62 vs $9.00 \pm$ $0.47 ; \mathrm{p}=0.001)$.

On the $14^{\text {th }}$ day after injury, the highest mean number of macrophages were seen in the negative control group (II), followed by the treatment group (III), and followed by the standard group (I). From the post hoc test results, it appeared that there were significant differences in the mean number of macrophages $(\mathrm{p}<0.05)$ in groups I-14 vs II-14 $(0.61 \pm 0.39$ 


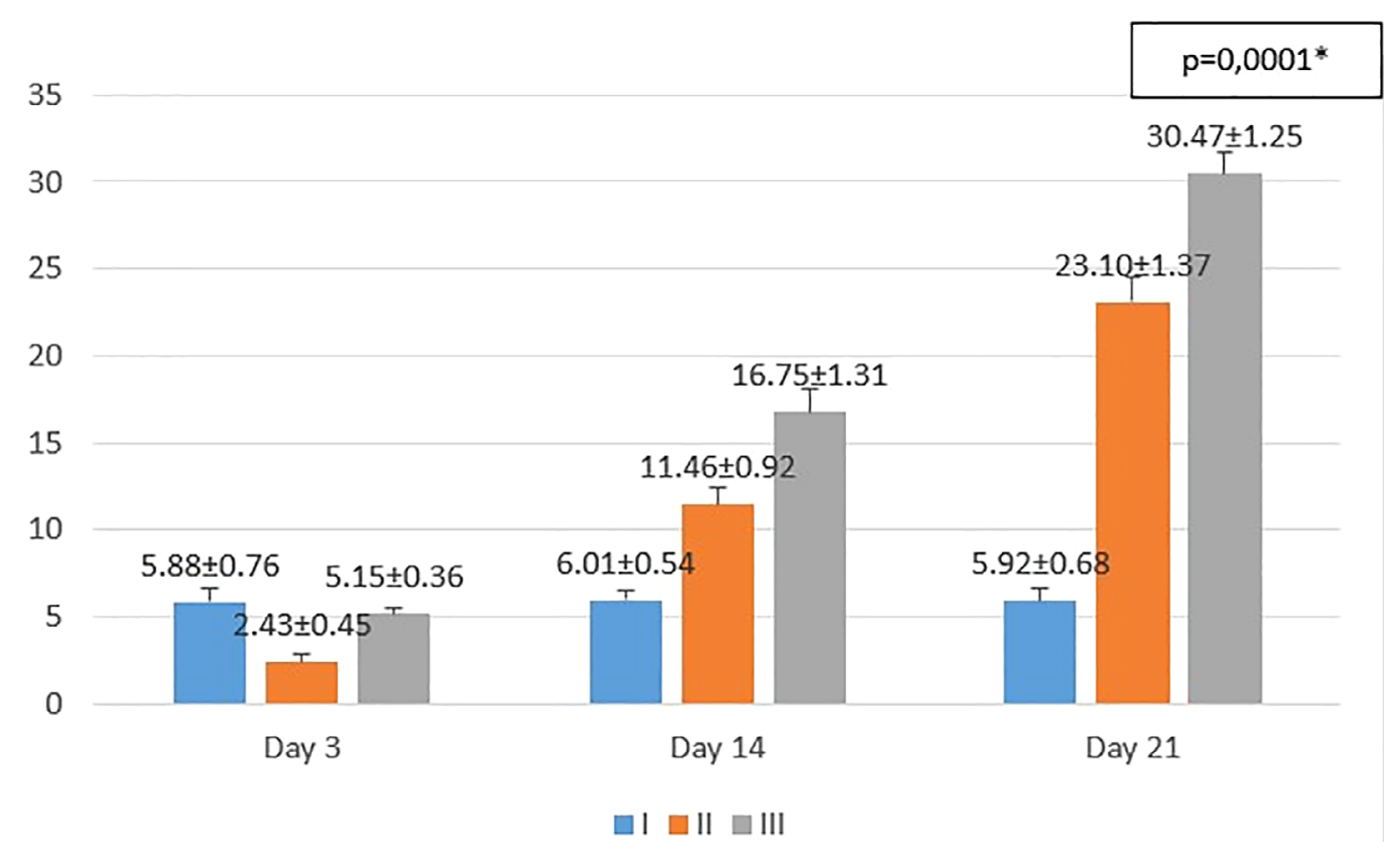

Figure 3. Mean number of epidermal thickness I (standard), II (negative control), III (treatment) * $p<0.05$ statistically analysis by ANOVA showed significant difference.

vs $6.22 \pm 0.98 ; \mathrm{p}=0.0001)$, group I-14 vs. III-14 (0.61 \pm 0.39 vs. $5.33 \pm 0.42 ; \mathrm{p}=0.0001)$, and group II-14 vs. III-14 (6.22 \pm 0.98 vs $5.33 \pm 0.42 ; \mathrm{p}=0.013)$.

On day $21^{\text {st }}$ day after injury, the highest mean number of macrophages were seen in the negative control group (II), followed by the treatment group (III), and followed by the standard group (I). From the post hoc test results, it appeared that there were significant differences in the mean number of macrophages $(\mathrm{p}<0.05)$ in groups I-21 vs II-21 $(0.55 \pm 0.40$ vs $4.72 \pm 0.87 ; \mathrm{p}=0.0001)$, group I-21 vs III- 21 ( $0.55 \pm 0.40$ vs $3.16 \pm 0.34 ; \mathrm{p}=0.0001)$, and group II- 14 vs III-14 (4.72 \pm 0.87 vs $3.16 \pm 0.34 ; \mathrm{p}=0.0001$ ).

On the $3^{\text {rd }}$ day after injury, the highest mean number of fibroblasts were seen in the treatment group (III), followed by the negative control group (II), and followed by the standard group (I). From the post hoc test results, it appeared that there were significant differences in the mean number of fibroblasts $(\mathrm{p}<0.05)$ in groups I-3 vs II-3 (3.77 \pm 0.34 vs. $4.61 \pm 0.49$; p=0.047), group I-3 vs III-3 (3.77 \pm 0.34 vs. $6.44 \pm 0.74 ; \mathrm{p}=0.0001)$, and group II-3 vs. III-3 (4.61 \pm 0.49 vs $6.44 \pm 0.74$; $\mathrm{p}=0.0001)$.

On the $14^{\text {th }}$ day after injury, the highest mean number of fibroblasts were seen in the treatment group (III), followed by the negative control group (II), and followed by the standard group (I). From the post hoc test results, it appeared that there were significant differences in the mean number of fibroblasts $(\mathrm{p}<0.05)$ in groups I-14 vs II-14 (3.94 \pm 0.38 vs $8.11 \pm$ $0.68 ; \mathrm{p}=0.0001)$, group I-14 vs III-14 (3.94 \pm 0.38 vs $21.55 \pm 1.02 ; \mathrm{p}=0.0001)$, and group II-14 vs III-14 (8.11 \pm 0.68 vs. $21.55 \pm 1.02 ; \mathrm{p}=0.0001)$.

On the $21^{\text {st }}$ day after injury, the highest mean number of fibroblasts were seen in the negative control group (II), followed by the treatment group (III), and followed by the standard group (I). From the post hoc test results, it appeared that there were significant differences in the mean number of fibroblasts $(\mathrm{p}<0.05)$ in groups I-21 vs II-21 $(3.72 \pm 0.38$ vs. $9.05 \pm$ $0.80 ; \mathrm{p}=0.0001)$, group I-21 vs III-21 (3.72 \pm 0.38 vs $6.66 \pm 1.05 ; \mathrm{p}=0.0001)$, and group II-21 vs III-21 (9.05 \pm 0.80 vs $6.66 \pm 1.05 ; \mathrm{p}=0.0001)$.

On the $3^{\text {rd }}$ day after injury, the mean epidermal thickness was highest in the standard group (I), followed by the treatment group (III), and followed by the negative control group (II). From the post hoc test results, it appeared that there were significant differences in the mean epidermal thickness $(\mathrm{p}<0.05)$ in groups I-3 vs II-3 (5.88 \pm 0.76 vs $2.43 \pm 0.45$; $\mathrm{p}=0.0001$ ), group II-3 vs III-3 ( $2.43 \pm 0.45$ vs. $5.15 \pm 0.36$; $\mathrm{p}=0.0001)$, while group I-3 vs. III-3 (5.88 \pm 0.76 vs. $5.15 \pm$ $0.36 ; \mathrm{p}=0.182$ ) did not show a significant result. 
On the $14^{\text {th }}$ day after injury, the mean epidermal thickness was highest in the treatment group (III), followed by the negative control group (II), and followed by the standard group (I). From the post hoc test results, it appeared that there were significant differences in the mean epidermal thickness $(\mathrm{p}<0.05)$ in groups I-14 vs II-14 (6.01 \pm 0.54 vs $11.46 \pm$ $0.92 ; \mathrm{p}=0.0001)$, group I-14 vs III-14 (6.01 \pm 0.54 vs $16.75 \pm 1.31 ; \mathrm{p}=0.0001)$, and group II-14 vs III-14 (11.46 \pm 0.92 vs. $16.75 \pm 1.31 ; \mathrm{p}=0.0001)$.

On the $21^{\text {st }}$ day after injury, the mean epidermal thickness was highest in the treatment group (III), followed by the negative control group (II), and followed by the standard group (I). From the post hoc test results, it appeared that there were significant differences in the mean epidermal thickness $(\mathrm{p}<0.05)$ in groups I-21 vs II-21 (5.92 \pm 0.68 vs. $23.10 \pm$ 1.37; $\mathrm{p}=0.0001)$, group I-21 vs III-21 (5.92 \pm 0.68 vs $30.47 \pm 1.25 ; \mathrm{p}=0.0001)$, and group II-21 vs III-21 (23.10 \pm 1.37 vs. $30.47 \pm 1.25 ; \mathrm{p}=0.0001$ ).

\section{Discussion}

Macrophages are cells that multiply when there is a wound to phagocytose debris and bacteria and they are the predominant cells on the $3^{\text {rd }}$ day post wound infliction (Gurtner \& Wong, 2013). This study showed that both negative control and treatment groups had more number of macrophages than standard group on the $3^{\text {rd }}$ day after injury. On the same day, the treatment group had more macrophages than negative control group because there is acemannan in aloe gel that could increase the number of macrophages (Sierra-García et al., 2014). The results of this study showed that there was reduction in number of macrophages in the treatment group than negative control group on the $14^{\text {th }}$ and $21^{\text {st }}$ day after injury. Souza et al. (2017) reported decrease in the number of macrophages in burn rats treated with $1 \%$ silver sulfadiazine.

In this study, both the $3^{\text {rd }}$ and $14^{\text {th }}$ days after injury demonstrated higher number of fibroblasts in the treatment group than negative control group. This might have happened because of interaction between glucomannan in aloe gel and gibberellin, a growth hormone, with growth factor receptors on fibroblast. This interaction stimulated fibroblast activity and proliferation that could increase collagen synthesis (Chithra et al., 1998; Surjushe et al., 2008). Besides that, there was also acemannan in aloe gel which could increase the proliferation of fibroblasts (Xing et al., 2014). Fibroblasts are cells that will increase its migration during proliferation phase of wound healing. Therefore, this study showed highest number of fibroblasts on the $14^{\text {th }}$ day after injury in the treatment group which was earlier than the negative control group that had the highest number on the $21^{\text {st }}$ day after injury. At some point during the proliferation phase, there may be apoptosis of fibroblast when collagen matrix has filled the wound cavity (Gurtner \& Wong, 2013). Therefore, there was reduction in the number of fibroblast on the $21^{\text {st }}$ day after injury in the treatment group.

Re-epithelialization occurs right after injury that consists of migration, proliferation and differentiation of keratinocytes (Gurtner \& Wong, 2013; Isrofah and Afandi, 2015). Acemannan could stimulate fibroblast to release keratinocyte growth factor-1 (KGF-1) that could hasten the re-epithelialization process by keratinocyte which could increase the epidermal thickness (Jettanacheawchankit et al., 2009). The result of this study showed that there was an increase in the epidermal thickness in both, negative control and treatment groups from the $3^{\text {rd }}$ day to $21^{\text {st }}$ day after injury. But the treatment group had thicker epidermis than negative control group that might be caused by acemannan. An in vitro study conducted by Teplicki et al. (2018) demonstrated that Aloe vera could speeded up the migration and proliferation of keratinocyte. Another study conducted by Atiba et al. (2015) showed that Aloe vera could enhance the re-epithelialization process in corneal alkali burn in normal and diabetic rats.

\section{Conclusion}

This study showed that Aloe vera extract gel could accelerate the healing process of burns in rats.

\section{Data Availability}

Underlying Data

Figshare: Effect of Aloe Vera in post-burn skin repair in rats

https://doi.org/10.6084/m9.figshare.17194973.v1

\section{Reporting guidelines}

Figshare: ARRIVE checklist for 'Effect of Aloe Vera in Post-Burn Skin Repair in Rats' (Aulia and Pane, 2022)

\section{https://doi.org/10.6084/m9.figshare.17194973.v1}

Data are available under the terms of the Creative Commons Zero "No rights reserved" data waiver (CC0 1.0 Public domain dedication). 


\section{Author Contributions}

Aulia L: Conceptualization, Formal Analysis, Investigation, Writing - Original Draft Preparation; Pane YS: Conceptualization, Formal Analysis, Writing - Original Draft Preparation, Writing - Review \& Editing

\section{Acknowledgement}

The authors give their appreciation and thanks to the Pharmacology Laboratory of the Faculty of Medicine, Universitas Sumatera Utara for allowing them to use the facility for collecting data for this research.

\section{References}

ABA: Advanced Burn Life Support Course Provider Manual.American Burn Asociation; 2018.

ABA: 2019 ABA NBR Annual Report - American Burn Association. 2019. accessed 9 April 2021

Reference Source

Atiba A, Wasfy $T$, Abdo W, et al.: Aloe vera gel facilitates

re-epithelialization of corneal alkali burn in normal and diabetic rats.

Clin. Ophthalmol. 2015.

Publisher Full Text

Aulia L, Pane YS: Effect of Aloe vera extract in post-burn skin repair in rats. Figshare Dataset. 2022.

Chaby G, Viseux V, Poulain JF, et al.: Topical silver sulfadiazine-induced acute renal failure. Annales de Dermatologie et de Venereologie. 2005; 132 891-893.

PubMed Abstract

Chithra P, Sajithlal GB, Chandrakasan G: Influence of Aloe vera on collagen characteristics in healing dermal wounds in rats. Mol. Cell. Biochem. 1998; 181: 71-76.

Publisher Full Text

Federer WY: Experimental Design, Theory and Application. New York: Mac Millan; 1963; 544

Reference Source

Fuller FW, Engler PE: Leukopenia in non-septic burn patients receiving topical 1\% silver sulfadiazine cream therapy: A survey. J. Burn Care

Rehabil. 1988; 9: 606-609.

PubMed Abstract | Publisher Full Text

Gazali A, Ibnu I, Suriah: Perilaku Pencarian Pengobatan Terhadap Kejadian Penyakit Malaria Pada Suku Mandar Di Desa Lara Kecamatan Karossa Kabupaten Mamuju Provinsi Sulawesi Barat. Fakultas Kesehatan Masyarakat Universitas Hasanudin. 2013; 1-13.

Gurtner GC, Wong VW: Wound Healing: Normal and Abnormal.Grabb and Smith's Plastic Surgery. Lippincott Williams \& Wilkins;7th edn 2013.

Isrofah S, Afandi M: Efektivitas Salep Ekstrak Daun Binahong (Anredera Cordifolia (Ten) Steenis) Terhadap Proses Penyembuhan Luka Baka Derajat 2 Termal pada Tikus Putih. Muhammadiyah Journal of Nursing. 2015.

Jettanacheawchankit S, Sasithanasate S, Sangvanich P, et al.: Acemannan stimulates gingival fibroblast proliferation; expressions of keratinocyte growth factor-1, vascular endothelial growth factor and type I collagen; and wound healing. J. Pharmacol. Sci. 2009; 109: 525-531.

PubMed Abstract | Publisher Full Text
Kristyaningsih P: Efektivitas Lidah Buaya (Aloe Vera) Dan Daunsirih (Piper Betle Linn) Terhadap Kesembuhan Luka Bakar Derajat Ii Pada Tikus Putih (Rattus Norvegicus Strain Wistar) Di Peternakan Tikus Sidomulyo Kediri. Jurnal Ilmu Kesehatan. 2016; 5: 114-121.

Maulana RA: Faktor Resiko yang Berperan pada Mortalitas Penderita Luka Bakar Rawat Inap di RSUPH Adam Malik Medan dari Tahun 2011-2014. Universitas Sumatera Utara; 2014.

Menkes: Pedoman Nasional Pelayanan Kedokteran - Tata Laksana Luka Bakar. Keputusan Menteri Kesehatan Republik Indonesia. 2019.

Reinke JM, Sorg H: Wound repair and regeneration. Eur. Surg. Res. 2012; 49: $35-43$.

Publisher Full Text

Russell WMS, , Burch RL: The Principles of Humane Experimental Technique. London: Methuen\& Co.Ltd; 1992. (Reissued: Universities Federation for

Animal Welfare, Herts, England.) 1959.

Reference Source

Sierra-García GD, Castro-Ríos R, González-Horta A, et al.: Acemannan, an extracted polysaccharide from Aloe vera: A literature review. Nat.

Prod Commun. 2014: 9: 1934578X1400900.

Publisher Full Text

Smolle C, Cambiaso-Daniel J, Forbes AA, et al.: Recent trends in burn epidemiology worldwide: A systematic review. Burns. 2017; 43 .

249-257.

PubMed Abstract | Publisher Full Text

Souza HR, De Azevedo LR, Possebon L, et al.: Heterogeneity of mast cells and expression of Annexin A1 protein in a second degree burn mode with silver sulfadiazine treatment. PLOS ONE. 2017; 12: e0173417.

PubMed Abstract | Publisher Full Text

Surjushe A, Vasani R, Saple D: Aloe vera: A short review Indian J. Dermatol. 2008; 53: 163-166.

PubMed Abstract | Publisher Full Text

Teplicki E, Ma Q, Castillo DE, et al.: The effects of aloe vera on wound healing in cell proliferation, migration, and viability. Wounds. 2018; 30 : 263-268.

PubMed Abstract

WHO:WHO|Burns. 2018.accessed 29 May 2021.

Reference Source

Xing W, Guo W, Zou CH, et al.: Acemannan accelerates cell proliferation and skin wound healing through AKT/mTOR signaling pathway.

J. Dermatol. Sci. 2014; 79: 101-109.

Publisher Full Text 


\section{Open Peer Review}

\section{Current Peer Review Status: ? X}

\section{Version 1}

Reviewer Report 28 April 2022

https://doi.org/10.5256/f1000research.83532.r128998

(C) 2022 Ali F. This is an open access peer review report distributed under the terms of the Creative Commons Attribution License, which permits unrestricted use, distribution, and reproduction in any medium, provided the original work is properly cited.

\section{Fatima Ali}

Applications of Stem Cells in Cancer Therapy: A Literature Based Studies, University of Lahore, Lahore, Pakistan

Major:

1. The authors mainly focuses on wound repair after burn injury but fail to show the result. Only the data of fibroblast and macrophages did not justify the whole questions? To answer this question author must show picture of wound healing, histopathological picture, wound healing area,

2. How authors say that the size of $2 \times 2 \mathrm{~cm} 2$ is reduced? Author must show the data about the wound healing in term of wound healing picture and wound healing area?

3. Images of a H\&E staining should be provided and correlate it with number of fibroblast and other mentioned cells.

4. Improve the scientific language.

Is the work clearly and accurately presented and does it cite the current literature? Partly

Is the study design appropriate and is the work technically sound? Partly

Are sufficient details of methods and analysis provided to allow replication by others? No

If applicable, is the statistical analysis and its interpretation appropriate? Partly

Are all the source data underlying the results available to ensure full reproducibility? 
Yes

Are the conclusions drawn adequately supported by the results?

Partly

Competing Interests: No competing interests were disclosed.

Reviewer Expertise: Stem cell

I confirm that I have read this submission and believe that I have an appropriate level of expertise to state that I do not consider it to be of an acceptable scientific standard, for reasons outlined above.

Author Response 30 Jun 2022

Yunita Sari Pane

Dear Fatima Ali,

Thank you for the comments on our manuscript. I would like to highlight some particulars regarding the work we have done according to the comments:

1. We have revised the results section regarding histopathological images as microscopic parameters. So, we don't need to show a picture of wound healing (macroscopic parameters), because it isn't in accordance with the aim of this study i.e: mean number of macrophages, number of fibroblasts, and epidermal thickness.

2. In this study, there is no statement of a reduction in burns. As for the information about $2 \times 2 \mathrm{~cm} 2$, it is the area of the wound that was determined in this study ( see in wound inflection part of the method).

3. In the revision, we have added histopathological images of macrophages, fibroblasts, and epidermal thickening. the explanation histopathological picture can be correlated with pictures 1, 2, and 3 (see results section).

4. Thank you for your suggestion, we will try to improve our ability in scientific language.

Competing Interests: No competing interests were disclosed.

Reviewer Report 28 February 2022

https://doi.org/10.5256/f1000research.83532.r123296

(C) 2022 Rusip G. This is an open access peer review report distributed under the terms of the Creative Commons Attribution License, which permits unrestricted use, distribution, and reproduction in any medium, provided the original work is properly cited. 


\author{
Gusbakti Rusip \\ Department of Physiology, Faculty of Medicine, Universitas Prima Indonesia, Sumatera Utara, \\ Indonesia
}

The manuscript by Lusiana Aulia and Yunita Sari Pane presents the intervening Effect of Aloe vera extract in post-burn skin repair in rats. In general, I find this manuscript to make an important contribution in developing palatable and superior bioactive compounds in Aloe vera containing various active ingredients that help the wound healing process, such as glucomannan and acemannan. However, I have outlined below some of the issues that need to be addressed prior to indexing, and some minor comments and suggestions to further improve the quality of the manuscript.

\title{
Major
}

1. In the abstract and introduction, the author states that one of the objectives of this study is to improve post-burn skin with the intervention of Aloe vera extract. However, histopathological description of the healing process of burns is not presented and discussed.

2. The method part is not clear. It is not clear the analytical method for macrophage and fibroblast counts and the analytical formula is not specified, the authors need to explain it. Please clarify and make changes to the methods section as appropriate.

3. In the discussion section, it is not explained how this study shows a synergistic interaction between changes that occur on days 3,14 and 21 and between a number of macrophages and fibroblasts in figures 1, 2 and 3 with no visible histopathologic changes. It's better to call it the calculation score.

\section{Minor}

1. In the method section, how much Aloe vera contains? Explain the total solids content of the gel material used in the study.

2. In the results section, a description of the histopathological picture is explained in relation to the analysis results from figures 1,2 and 3. It would be easier to explain in the discussion section.

3. In the discussion section, please explain clearly the bioactive compounds contained in Aloe vera other than glucomannan and acemannan. Are there other active ingredients? What do the authors mean treatment days 14 and 21? Describe the histopathological picture with figures 1,2 and 3 .

4. In the introduction and abstract, Aloe vera intervention changes macrophages, fibroblasts and increases bioactive compounds and their potential for healing functional burns. The conclusion states that it is a potential pharmaceutical product. Please be consistent.

Is the work clearly and accurately presented and does it cite the current literature? Yes

Is the study design appropriate and is the work technically sound? 
Yes

Are sufficient details of methods and analysis provided to allow replication by others? Yes

If applicable, is the statistical analysis and its interpretation appropriate? Partly

Are all the source data underlying the results available to ensure full reproducibility? Yes

Are the conclusions drawn adequately supported by the results? Yes

Competing Interests: No competing interests were disclosed.

Reviewer Expertise: Physiology human, exercise, and much research-related use plants as herbal medicine

I confirm that I have read this submission and believe that I have an appropriate level of expertise to confirm that it is of an acceptable scientific standard, however I have significant reservations, as outlined above.

\section{Author Response 09 Mar 2022}

\section{Yunita Sari Pane}

Dear Prof Gusbakti Rusip,

I really appreciate your willingness to review my manuscript. Here I explain more information to improve understanding in this article.

Major:

1. We have assessed entirely during the present study, but I couldn't document all due to lack of memory byte card on the camera, So I took a few photos that can represented it and can be seen in figshare ( https://doi.org/10.6084/m9.figshare.17194973.v1)

2. We used the ANOVA test because in this study we used more than two groups with parametric data types

3. We have presented and correlated the changes that occur on days $3,14,21$ in macrophages and fibroblasts that could be seen in Figures 1 and 2 and had been discussed in the discussion section.

Minor:

1. Aloe vera contained $10 \%$ of the total weight of the gel (see gel preparation)

2. In journal writing, repetition of words should be avoided, therefore we chose to 
explain in detail the number and comparison between groups in the results section. While in the discussion section we explained the comparison of our findings with other studies

3. Aloe vera has active ingredients other than acemannan and glucomannan, but based on the literature that we read, it proved that they could play a role in burn repair.

4. We did not state that aloe vera can be used as a pharmaceutical product in the conclusion section (see part conclusion). We only stated that aloe vera could accelerate the healing process as proven by this study.

Competing Interests: No competing interests were disclosed.

The benefits of publishing with F1000Research:

- Your article is published within days, with no editorial bias

- You can publish traditional articles, null/negative results, case reports, data notes and more

- The peer review process is transparent and collaborative

- Your article is indexed in PubMed after passing peer review

- Dedicated customer support at every stage

For pre-submission enquiries, contact research@f1000.com 